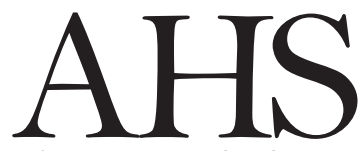

Advances in Horticultural Science

\title{
Effect of vine and fruit pruning on yield attributes of two watermelon (Citrullus lanatus) cultivars
}

\author{
A. Ndereyimana ${ }^{1}(*)$, B.W. Waweru ${ }^{1}$, B. Kagiraneza ${ }^{1}$, A. N. Niyokuri ${ }^{2}$, P. \\ Rukundo $^{1}$, G. Hagenimana ${ }^{1}$ \\ 1 Rwanda Agriculture and Animal Resources Development Board (RAB), \\ Agriculture Innovation and Technology Transfer Department, P.O. Box 5016, \\ Kigali, Rwanda. \\ 2 Department of Crop Sciences, College of Agriculture, Animal Sciences and \\ Veterinary Medicine, University of Rwanda, P.O. Box 210, Musanze, Rwanda.
}

Key words: Apical shoot pinching, cucurbits, fruit pinching, fruit size, hybrid.

OPEN ACCESS

${ }^{(*)}$ Corresponding author:
assinapol.ndereyimana@rab.gov.rw

Citation:

NDEREYIMANA A., WAWERU B.W., KAGIRANEZA B., NIYOKURI A.N., RUKUNDO P., HAGENIMANA

G., 2021 - Effect of vine and fruit pruning on yield attributes of two watermelon (Citrullus lanatus) cultivars. - Adv. Hort. Sci., 35(3): 269-275

Copyright:

(C) 2021 Ndereyimana A., Waweru B.W., Kagiraneza B., Niyokuri A.N., Rukundo P., Hagenimana G. This is an open access, peer reviewed article published by Firenze University Press (http://www.fupress.net/index.php/ahs/) and distributed under the terms of the Creative Commons Attribution License, which permits unrestricted use, distribution, and reproduction in any medium, provided the original author and source are credited.

Data Availability Statement: All relevant data are within the paper and its Supporting Information files.

Competing Interests:

The authors declare no competing interests.
Abstract: This study was carried out to determine the effect of vine and fruit pruning on watermelon (Citrullus lanatus) yield. Five pruning methods: P1=no pruning at all, $\mathbf{P 2}=$ pruning to four vines with two fruits per vine, $\mathrm{P} 3=$ =pruning to four vines with one fruit per vine, $P 4=$ pruning to three vines with two fruits per vine and $P 5=$ pruning to three vines with one fruit per vine were evaluated on two watermelon cultivars: 'Sugar baby' and 'Julie F1' under a factorial randomized complete block design with three replications. Investigations were carried out in the seasons 2017A (short rains) and 2017B (long rains) at Karama and Rubona experimental sites belonging to Rwanda Agriculture and Animal Resources Development Board. The obtained results indicated a significant difference among the different cultivars and pruning methods tested during both seasons and at two sites. Generally, all studied parameters recorded higher values during season 2017B than in season 2017A at Rubona site. A similar trend was recorded at Karama site except that the fruit yield per plant and per hectare for plants which were pruned to three vines with one fruit reduced during season 2017B as compared to season 2017A. The highest number of fruits per plant, fruit weight, fruit yield per plant and per hectare was recorded in 'Julie F1' compared to 'Sugar baby' at both sites and during both seasons. Higher fruit weight was obtained when both cultivars were pruned to three or four vines with one fruit per vine. Higher number of fruits per plant and higher fruit yield per plant was observed under pruning to four vines with two fruits per vine at Rubona site; while at Karama site, higher fruit yield per plant was recorded under pruning to three vines with one fruit or two fruits per vines and pruning to four vines with two fruits per vine. A similar trend was observed in fruit yield per hectare. Based on results of the current study, cultivation of the hybrid 'Julie F1' and pruning to three vines with one fruit per vine is recommended for optimum watermelon yield with big-sized fruits.

\section{Introduction}

Watermelon is a crop belonging to the Cucurbitaceae family that has gained a great economic importance due to its delicious fruits that are also rich in various nutritional compounds (Kong et al., 2017). During the 
year 2018, the worldwide watermelon production was $103,931,337 \mathrm{t}$ harvested over an area of $3,241,239$ ha with the yield of $32.1 \mathrm{t} \mathrm{ha}^{-1}$ (FAO, 2020); while in East Africa, it was 230,729 t from an area of 12,110 ha with the yield of only $19.1 \mathrm{t} \mathrm{ha}^{-1}$. The yield gap of $13 \mathrm{t} \mathrm{ha-}{ }^{1}$ compared to the world's yield can be addressed by improving production practices, including regulation of number of vines and fruits per plant (Oga and Umekwe, 2016; Dube et al., 2020).

As other cucurbits, watermelon is also a crop with vines on which female flowers appear after about every five male flowers (Dube et al., 2020). The number of vines per plant is an important parameter determining the performance of Cucurbitaceae crops, including watermelon (Gomes et al., 2019). On the other side, the number of fruits per vine is also an important parameter that determines fruit size, mass and yield (Lins et al., 2013). Therefore, due consideration given to these aspects of cucurbit management is of utmost importance. In cucurbits, regulation of number of vines per plant and fruits per vine can be achieved through different methods including vine and fruit pruning (Campos et al., 2019).

Pruning is a special horticultural practice that is carried out by removing some parts of plant to boost flowering and subsequent fruiting. This leads to improved yield with enhancement in features required by consumers, such as fruit size and appearance (Oga and Umekwe, 2016). The main purpose of pruning is to promote balance between vegetative growth and fruit load (Anwar et al., 2019). Pruning has been reported to increase yield of cucumber (Nayak et al., 2018) and butternut (Eve et al., 2016). Pruning is also a common practice in watermelon production that can lead to synchronization of harvesting period and production of uniform fruits (Oga and Umekwe, 2016).

In East African countries, limited investigations have been carried out on watermelon as compared to legume and cereal crops (Dube et al., 2020). Besides, East African farmers rarely practice watermelon pruning due to limited knowledge on appropriate pruning method. The study was carried out to determine the effect of vine and fruit pruning on yield attributes of two watermelon cultivars.

\section{Materials and Methods}

Sites and seasons of study

Field experiment was carried out at Karama and
Rubona experimental sites belonging to Rwanda Agriculture and Animal Resources Development Board (RAB). Karama site is located in Eastern Province, Bugesera District, on longitude $02^{\circ} 23^{\prime} 15^{\prime \prime} S$, latitude $30^{\circ} 11^{\prime} 27^{\prime \prime} E$, and at an altitude of $1524 \mathrm{~m}$ above sea level (Ndabamenye et al., 2013; Kabirigi et al., 2017). Its annual average rainfall is $850-1100 \mathrm{~mm}$ and the average temperature is $20-21^{\circ} \mathrm{C}$ (Verdoodt and Van Ranst, 2003). Rubona site is located in Southern Province, Huye District, on longitude $029^{\circ} 46^{\prime} 475^{\prime \prime} E$, latitude $02^{\circ} 29^{\prime} 327^{\prime \prime} S$, and at an altitude of $1727 \mathrm{~m}$ above sea level (Ndabamenye et al., 2013; Kabirigi et al., 2017). The annual average rainfall at Rubona is $1100-1400 \mathrm{~mm}$ and the average temperature is $17-20^{\circ} \mathrm{C}$ (Verdoodt and Van Ranst, 2003).

At both sites, the study was conducted in two cropping seasons: Season 2017A (short rain season) covering the period from September to December 2016 and Season 2017B (long rain season) from February to May 2017.

\section{Study design and treatments}

The study was conducted in a factorial randomized complete blocks design (RCBD) where treatments were replicated thrice. The treatment structure consisted of five different pruning methods (factor one) evaluated on two watermelon cultivars (factor two). The five pruning methods were designed as follows: $\mathrm{P} 1=$ No pruning at all (control), $\mathrm{P} 2=$ Pruning to four vines with two fruits per vine, $P 3=$ Pruning to four vines with one fruit per vine, $\mathrm{P} 4=$ Pruning to three vines with two fruits per vine, and $P 5=$ Pruning to three vines with one fruit per vine. The two studied watermelon cultivars were C1: 'Sugar baby' and C2: 'Julie F1'. These cultivars were selected because of their high yield potential under breeder's conditions. Moreover, 'Julie F1' is a popular hybrid among farmers in East African Region. In total, ten treatment combinations (cultivar $x$ pruning method) were studied.

\section{Trial establishment and maintenance}

Field was ploughed twice at an interval of two weeks and was subdivided into plots of $6 \mathrm{~m} \times 3 \mathrm{~m}$ that were mulched using dry grass. There were ten plots in each replication; and each plot received a treatment combination of cultivar and pruning method. Watermelon seedlings for each cultivar were raised in biodegradable pots and transplanted 30 days after sowing at a spacing of $3 \mathrm{~m} \times 2 \mathrm{~m}$. Pruning was achieved by pinching the apical shoot of watermelon vine after six nodes, about 18 days after 
transplanting (Anwar et al., 2019). Then, at 15 days after pinching, four vines were maintained for $\mathrm{P} 2$ and P3 treatments while three vines were maintained for P4 and P5. Thereafter, two fruits were maintained per vine for $\mathrm{P} 2$ and $\mathrm{P} 4$ while one fruit was maintained per vine for P3 and P5. For all the treatments where pruning was carried out, one of the maintained vines was not allowed to have fruits for it to support other in feeding their fruits.

Apart from watermelon cultivars and pruning methods, other crop management practices such as fertilization, watering, weeding, pests and diseases management were carried out as recommended. Fertilization was conducted by applying organic manure and the inorganic fertilizer $\mathrm{N}: \mathrm{P}: \mathrm{K}$ at the rates of $25 \mathrm{t} \mathrm{ha}^{-1}$ and 90:60:60 kg ha-1, respectively. The inorganic fertilizer NPK 17-17-17 was used to supply 60:60:60 $\mathrm{kg} \mathrm{ha}^{-1}$, which was given in two equal splits (at transplanting and at one month after transplanti$\mathrm{ng}$ ); while additional $30 \mathrm{~kg}$ of $\mathrm{N} \mathrm{ha}^{-1}$ was supplied in form of urea $46 \%$ and was given at two months after transplanting. Where necessary, copper oxychloride and carbendazim pesticides were sprayed to control diseases while Lambda-Cyhalothrin and imidacloprid were used against pests.

\section{Data collection and analysis}

Observations were carried out on four randomly selected plants per each treatment combination. Data were recorded on number of fruits per plant, fruit weight, fruit yield per plant and fruit yield per hectare. The number of fruits per plant was obtained at harvesting through counting all available fruits on four selected plants per treatment combination followed by calculating the average per plant. Fruit weight ( $\mathrm{kg}$ ) was achieved as the average of five fruits randomly selected from the fruits harvested on the four pre-selected observational plants. Fruit yield per plant $(\mathrm{kg})$ was recorded as the average weight of all fruits harvested from four observational plants in the plot under consideration. Fruit yield per hectare was derived from computation using the data on fruit yield per plant. Analysis of variance for the collected data was performed using GenStat $14^{\text {th }}$ Edition software package and the level of significance was set at $P<0.05$. Least significant difference (LSD) test was conducted for pair-wise comparisons of means.

\section{Results}

The number of fruits per plant differed significant- ly $(P<0.05)$ between cultivars in both seasons $(2017 \mathrm{~A}$ and 2017B) at Karama site. Significant differences among pruning methods were recorded only in season 2017A at Karama and in both seasons at Rubona. Between the two cultivars, the highest number of fruit per plant was recorded in 'Julie F1' (3.5-4.0 fruits per plant) compared to 'Sugar baby' (3.4-3.7 fruits per plant). For pruning method, the highest number of fruit per plant (4.1-4.8 fruits per plant) at Karama site was recorded when both watermelon cultivars were pruned to four vines with two fruits per vine (Table 1). A similar trend was also observed at Rubona where both watermelon cultivars were pruned to four vines with two fruits per vine recorded the highest number of fruits per plant (4.8-5.0) (Table 2). There was no significant interaction among cultivars and pruning methods on the number of fruits per plant.

Fruit weight differed significantly $(P<0.05)$ between cultivars and among pruning methods. The highest fruit weight was recorded in plots where 'Julie F1' was planted at both sites and it varied between 3.8-3.9 kg per fruit at Karama site (Table 1) and 3.4-3.8 kg per fruit at Rubona site (Table 2). Among pruning methods, the highest fruit weight (4.2-4.3 kg at Karama and 3.7-4.1 kg at Rubona) was obtained when both cultivars were pruned to three vines with one fruit per vine during season 2017A and 2017B (Table 1 and 2). The interaction of cultivars and pruning methods on fruit weight in both 2017A and 2017B seasons at Rubona and at Karama during the season 2017A was significantly different. However, it was not significantly different in the season 2017B at Karama site. Higher fruit weight (4.1 4.6 kg per fruit) was obtained under 'Julie F1' pruned to three vines with one fruit per vine, followed by the same cultivar pruned to four vines with one fruit per vine (3.7-4.2 kg per fruit) (Tables 1 and 2).

Fruit yield per plant and per hectare was significantly $(P<0.05)$ different between cultivars and among pruning methods and their interaction in both seasons 2017A and 2017B, and at Karama and Rubona sites was not relevant. 'Julie F1' recorded significantly higher fruit yield per plant (11.9-15.4 kg) and per hectare (59.6t ha ${ }^{-1}-76.9 \mathrm{t} \mathrm{ha}^{-1}$ ) compared to Sugar baby which recorded 9.5-11.2 kg per plant and 47.5t-59.1t per hectare. Among the pruning methods, the highest fruit yield per plant $(13.9-15.9 \mathrm{~kg})$ and yield per hectare $\left(69.3 \mathrm{t} \mathrm{ha}^{-1}-78.0 \mathrm{t} \mathrm{ha}^{-1}\right)$ was observed under pruning to four vines with two fruits per vine at Rubona site (Table 2). At Karama site, 
Adv. Hort. Sci., 2021 35(3): 269-275

Table 1 - Performance of watermelon as affected by cultivars and pruning method, Karama Site

\begin{tabular}{|c|c|c|c|c|c|c|c|c|}
\hline \multirow[b]{2}{*}{ Treatments } & \multicolumn{2}{|c|}{ No. of fruits per plant } & \multicolumn{2}{|c|}{ Fruit weight (kg) } & \multicolumn{2}{|c|}{ Fruit yield (kg per plant) } & \multicolumn{2}{|c|}{ Fruit yield $\left(\mathrm{t} \mathrm{ha}^{-1}\right)$} \\
\hline & $\begin{array}{c}\text { Season } \\
2017 A\end{array}$ & $\begin{array}{l}\text { Season } \\
2017 B\end{array}$ & $\begin{array}{l}\text { Season } \\
2017 A\end{array}$ & $\begin{array}{c}\text { Season } \\
2017 B\end{array}$ & $\begin{array}{c}\text { Season } \\
2017 A\end{array}$ & $\begin{array}{c}\text { Season } \\
2017 B\end{array}$ & $\begin{array}{c}\text { Season } \\
2017 A\end{array}$ & $\begin{array}{l}\text { Season } \\
2017 B\end{array}$ \\
\hline \multicolumn{9}{|c|}{ Factor 1: Cultivar (C) } \\
\hline $\mathrm{C} 1$ & $3.4 \mathrm{~b}$ & $3.7 \mathrm{~b}$ & $3.2 \mathrm{~b}$ & $3.2 \mathrm{~b}$ & $10.8 \mathrm{~b}$ & $11.2 \mathrm{~b}$ & $54.1 \mathrm{~b}$ & $59.1 b$ \\
\hline $\mathrm{C} 2$ & $3.8 \mathrm{a}$ & $4.0 \mathrm{a}$ & $3.8 \mathrm{a}$ & $3.9 \mathrm{a}$ & $14.8 \mathrm{a}$ & $15.4 \mathrm{a}$ & $74.0 \mathrm{a}$ & 76.9 a \\
\hline Significance & $* * *$ & $* * *$ & $* * *$ & $* * *$ & $* * *$ & $* * *$ & $* * *$ & $* * *$ \\
\hline SED & 0.095 & 0.159 & 0.060 & 0.063 & 0.439 & 0.644 & 2.19 & 3.22 \\
\hline \multicolumn{9}{|c|}{ Factor 2: Pruning method $(P)$} \\
\hline P1 & $3.0 \mathrm{c}$ & 3.4 & $2.8 \mathrm{~d}$ & $2.9 \mathrm{e}$ & $8.6 \mathrm{c}$ & $10.0 \mathrm{c}$ & $43.2 \mathrm{c}$ & $49.7 \mathrm{c}$ \\
\hline P2 & $4.1 \mathrm{a}$ & 4.8 & $3.2 \mathrm{c}$ & $3.3 d$ & $13.5 \mathrm{~b}$ & $15.8 \mathrm{a}$ & $67.3 \mathrm{~b}$ & 78.9 a \\
\hline P3 & $3.5 \mathrm{~b}$ & 3.4 & $3.8 \mathrm{~b}$ & $3.8 \mathrm{~b}$ & $13.4 \mathrm{~b}$ & $13.2 \mathrm{~b}$ & $67.0 \mathrm{~b}$ & $65.7 \mathrm{~b}$ \\
\hline P4 & $3.6 \mathrm{~b}$ & 4.0 & $3.5 \mathrm{c}$ & $3.5 \mathrm{c}$ & $12.8 \mathrm{~b}$ & $14.2 \mathrm{ab}$ & $63.8 \mathrm{~b}$ & $71.1 \mathrm{ab}$ \\
\hline P5 & $3.7 \mathrm{ab}$ & 3.5 & $4.2 \mathrm{a}$ & $4.3 \mathrm{a}$ & $15.8 \mathrm{a}$ & $14.9 a b$ & $78.8 \mathrm{a}$ & $74.5 \mathrm{ab}$ \\
\hline Significance & $* * *$ & NS & $* * *$ & $* * *$ & $* * *$ & $* * *$ & $* * *$ & $* * *$ \\
\hline SED & 0.151 & 0.251 & 0.094 & 0.099 & 0.694 & 1.019 & 3.47 & 5.09 \\
\hline \multicolumn{9}{|c|}{ Interaction $(C \times P)$} \\
\hline C1P1 & 2.8 & 3.1 & $2.7 f$ & 2.7 & 7.7 & 8.5 & 38.3 & 42.4 \\
\hline C1P2 & 4.0 & 4.7 & $3.6 \mathrm{~cd}$ & 2.9 & 11.5 & 13.7 & 57.4 & 68.3 \\
\hline C1P3 & 3.3 & 3.4 & 3.4 de & 3.4 & 11.1 & 11.7 & 55.5 & 58.6 \\
\hline C1P4 & 3.3 & 3.8 & 3.1 ef & 3.1 & 10.3 & 11.9 & 51.5 & 59.7 \\
\hline C1P5 & 3.6 & 3.4 & $3.8 \mathrm{bcd}$ & 3.9 & 13.5 & 13.3 & 67.7 & 66.6 \\
\hline $\mathrm{C} 2 \mathrm{P} 1$ & 3.3 & 3.8 & 2.9 ef & 3.0 & 9.6 & 11.4 & 48.0 & 57.0 \\
\hline $\mathrm{C} 2 \mathrm{P} 2$ & 4.3 & 4.9 & $2.9 \mathrm{ef}$ & 3.6 & 15.4 & 17.9 & 77.2 & 89.5 \\
\hline $\mathrm{C} 2 \mathrm{P} 3$ & 3.7 & 3.4 & $4.2 \mathrm{ab}$ & 4.2 & 15.7 & 14.6 & 78.5 & 72.9 \\
\hline $\mathrm{C} 2 \mathrm{P} 4$ & 3.9 & 4.2 & $3.9 \mathrm{bc}$ & 3.9 & 15.2 & 16.5 & 76.2 & 82.6 \\
\hline $\mathrm{C} 2 \mathrm{P} 5$ & 3.9 & 3.6 & $4.6 \mathrm{a}$ & 4.6 & 18.0 & 16.5 & 90.0 & 82.4 \\
\hline Significance & NS & NS & $* * *$ & NS & NS & NS & NS & NS \\
\hline SED & 0.213 & 0.355 & 0.133 & 0.140 & 0.981 & 1.441 & 4.91 & 7.20 \\
\hline
\end{tabular}

$\mathrm{C} 1=$ Sugar baby, C2=Julie F1, P1=No pruning, P2= Pruning to 4 vines with 2 fruits per vine, $\mathrm{P} 3=$ Pruning to 4 vines with 1 fruit per vine, $\mathrm{P} 4=$ Pruning to 3 vines with 2 fruits per vine, $P 5=$ Pruning to 3 vines with 1 fruit per vine, 2017A=short rains, 2017B=long rains.

$\mathrm{SED}=$ Standard error difference.

$*$ and $* *=$ significant difference at $5 \%$ and $1 \%$ respectively, NS=not significantly different $(P>0.05)$.

Means within each column followed by the same letter are not significantly different as per LSD test at $\mathrm{P}<0.05$.

higher fruit yield per plant $(15.8 \mathrm{~kg})$ and per hectare (78.8 $\mathrm{t} \mathrm{ha}^{-1}$ ) was recorded under pruning to three vines with one fruit per vine during season $2017 \mathrm{~A}$ (Tables 1) while during season 2017B, higher fruit yield per plant and per hectare was recorded on watermelon plants that were pruned to three vines with one fruit per vine or four vines with one fruit or two fruits per vine (14.2-15.8 kg per plant and $71.1 \mathrm{t}$ $\mathrm{ha}^{-1}-78.9 \mathrm{t} \mathrm{ha}^{-1}$ ) (Table 1$)$.

\section{Discussion and Conclusions}

Among others, crops of Cucurbitaceous family can be manipulated by altering the source: sink ratio through stem and fruit pruning, which affects the number of leaves per plant and consequently leaf area (source) and demand for photoassimilates (sink) (Queiroga et al., 2008). In this family, more pruning studies have been carried out on other crops such as cucumber (Nayak et al., 2018) and butternut (Eve et al., 2016); there is limited information on this aspect as far as watermelon is concerned. Therefore, the current study contributed valuable knowledge on watermelon management in a view to optimize its production.

Heavier fruits obtained under watermelon plants (Julie F1) pruned to three or four vines with one fruit per vine fall in line with Lins et al. (2013) who reported that fruit thinning allows larger amounts of produced photo-assimilates to be used by few fruits causing them to attain a size demanded on market. Similar to results of the current study, Dhillon et al. (2017) also obtained heavier fruits on pruned cucum- 
Table 2 - Performance of watermelon as affected by cultivar and pruning method, Rubona Site

\begin{tabular}{|c|c|c|c|c|c|c|c|c|}
\hline \multirow[b]{2}{*}{ Treatments } & \multicolumn{2}{|c|}{ No. of fruits per plant } & \multicolumn{2}{|c|}{ Fruit weight (kg) } & \multicolumn{2}{|c|}{ Fruit yield (kg per plant) } & \multicolumn{2}{|c|}{ Fruit yield $\left(\mathrm{t} \mathrm{ha}^{-1}\right)$} \\
\hline & $\begin{array}{l}\text { Season } \\
2017 A\end{array}$ & $\begin{array}{c}\text { Season } \\
2017 B\end{array}$ & $\begin{array}{c}\text { Season } \\
2017 A\end{array}$ & $\begin{array}{c}\text { Season } \\
2017 B\end{array}$ & $\begin{array}{c}\text { Season } \\
2017 A\end{array}$ & $\begin{array}{c}\text { Season } \\
2017 B\end{array}$ & $\begin{array}{c}\text { Season } \\
2017 A\end{array}$ & $\begin{array}{l}\text { Season } \\
2017 B\end{array}$ \\
\hline \multicolumn{9}{|c|}{ Factor 1: Cultivar (C) } \\
\hline $\mathrm{C} 1$ & 3.4 & 3.6 & $2.8 \mathrm{~b}$ & $3.1 \mathrm{~b}$ & $9.5 \mathrm{~b}$ & $11.1 \mathrm{~b}$ & $47.5 b$ & $54.3 b$ \\
\hline $\mathrm{C} 2$ & 3.5 & 3.8 & $3.4 \mathrm{a}$ & $3.8 \mathrm{a}$ & $11.9 \mathrm{a}$ & $14.2 \mathrm{a}$ & $59.6 a$ & $69.9 a$ \\
\hline Significance & NS & NS & $* * *$ & $* * *$ & $* * *$ & $* * *$ & $* * *$ & $* * *$ \\
\hline SED & 0.198 & 0.182 & 0.051 & 0.057 & 0.617 & 0.643 & 3.08 & 3.10 \\
\hline \multicolumn{9}{|c|}{ Factor 2: Pruning method $(P)$} \\
\hline P1 & $3.0 \mathrm{~b}$ & $3.2 \mathrm{~b}$ & $2.5 \mathrm{e}$ & $2.8 \mathrm{e}$ & $7.6 \mathrm{c}$ & $9.0 \mathrm{c}$ & $38.0 \mathrm{c}$ & $44.0 \mathrm{c}$ \\
\hline P2 & $4.8 \mathrm{a}$ & $5.0 \mathrm{a}$ & $2.9 \mathrm{~d}$ & $3.2 \mathrm{~d}$ & $13.9 \mathrm{a}$ & 15.9 a & $69.3 \mathrm{a}$ & $78.0 \mathrm{a}$ \\
\hline P3 & $3.0 \mathrm{~b}$ & $3.2 \mathrm{~b}$ & $3.4 \mathrm{~b}$ & $3.7 \mathrm{~b}$ & $10.1 \mathrm{~b}$ & $12.1 \mathrm{~b}$ & $50.5 \mathrm{~b}$ & $59.0 \mathrm{~b}$ \\
\hline P4 & $3.5 b$ & $3.7 b$ & $3.1 \mathrm{c}$ & $3.4 \mathrm{c}$ & $10.9 \mathrm{~b}$ & $12.9 \mathrm{~b}$ & $54.3 \mathrm{~b}$ & $63.7 \mathrm{~b}$ \\
\hline P5 & $3.0 \mathrm{~b}$ & $3.2 \mathrm{~b}$ & $3.7 \mathrm{a}$ & $4.1 \mathrm{a}$ & $11.2 \mathrm{~b}$ & $13.3 \mathrm{~b}$ & $55.8 \mathrm{~b}$ & $65.9 \mathrm{~b}$ \\
\hline Significance & $* * *$ & $* * *$ & $* * *$ & $* * *$ & $* * *$ & $* * *$ & $* * *$ & $* * *$ \\
\hline SED & 0.312 & 0.288 & 0.081 & 0.090 & 0.975 & 1.016 & 10.25 & 4.90 \\
\hline \multicolumn{9}{|c|}{ Interaction $(C \times P)$} \\
\hline C1P1 & 2.7 & 2.9 & $2.4 \mathrm{f}$ & $2.7 \mathrm{f}$ & 6.5 & 7.7 & 32.3 & 37.4 \\
\hline C1P2 & 5.0 & 5.0 & $2.6 \mathrm{ef}$ & 2.9 ef & 12.9 & 14.3 & 64.3 & 69.9 \\
\hline C1P3 & 3.0 & 3.2 & $3.0 \mathrm{~d}$ & $3.3 \mathrm{~d}$ & 9.0 & 10.8 & 45.0 & 52.5 \\
\hline C1P4 & 3.3 & 3.6 & $2.7 \mathrm{e}$ & $3.0 \mathrm{e}$ & 9.1 & 10.8 & 45.5 & 52.9 \\
\hline C1P5 & 3.0 & 3.2 & $2.4 \mathrm{c}$ & $3.7 \mathrm{c}$ & 10.1 & 12.1 & 50.5 & 59.0 \\
\hline $\mathrm{C} 2 \mathrm{P} 1$ & 3.3 & 3.6 & $2.6 \mathrm{ef}$ & 2.9 ef & 8.7 & 10.4 & 43.7 & 50.6 \\
\hline $\mathrm{C} 2 \mathrm{P} 2$ & 4.7 & 5.0 & $3.2 \mathrm{~cd}$ & $3.6 \mathrm{~cd}$ & 14.9 & 17.6 & 74.3 & 86.1 \\
\hline $\mathrm{C} 2 \mathrm{P} 3$ & 3. & 3.2 & $3.7 \mathrm{~b}$ & $4.2 \mathrm{~b}$ & 11.2 & 13.4 & 56.0 & 65.5 \\
\hline $\mathrm{C} 2 \mathrm{P} 4$ & 3.7 & 3.9 & $3.4 \mathrm{c}$ & $3.8 \mathrm{c}$ & 12.6 & 14.9 & 63.2 & 74.5 \\
\hline $\mathrm{C} 2 \mathrm{P} 5$ & 3.0 & 3.2 & $4.1 \mathrm{a}$ & $4.5 \mathrm{a}$ & 12.2 & 14.6 & 61.0 & 72.9 \\
\hline Significance & NS & NS & $*$ & $*$ & NS & NS & NS & NS \\
\hline SED & 0.442 & 0.407 & 0.115 & 0.127 & 1.379 & 1.437 & 6.90 & 6.93 \\
\hline
\end{tabular}

$\mathrm{C} 1=$ Sugar baby, $\mathrm{C} 2=$ Julie F1, $\mathrm{P} 1=$ No pruning, $\mathrm{P} 2=$ Pruning to 4 vines with 2 fruits per vine, P3: Pruning to 4 vines with 1 fruit per vine, $\mathrm{P} 4=$ Pruning to 3 vines with 2 fruits per vine, P5= Pruning to 3 vines with 1 fruit per vine, 2017A=short rains, 2017B=long rains.

$\mathrm{SED}=$ Standard error difference.

$*$ and $* *=$ significant difference at $5 \%$ and $1 \%$ respectively, NS=not significantly different $(P>0.05)$.

Means within each column followed by the same letter are not significantly different as per LSD test at $\mathrm{P}<0.05$.

ber plants compared to unpruned ones. These findings could be further explained by the fact that plants with less branches allow more light interception and this leads to improved photosynthesis, more accumulation of carbohydrates, and thus overall improved crop performance as compared to plants with relatively higher number of branches (Feng et al., 2008). In agreement with the findings of current study, Ali et al. (2016) also reported interaction effect of cultivars and pruning on yield of bottle gourd (Lagenaria siceraria).

In this study, fruit and vine pruning have been observed to significantly affect watermelon yield. This would be attributed to the fact that stem and fruit density is among agronomic variables associated with yield performance of vegetable crops (AyalaTafoya et al., 2019). The number of stem per plant contributes to plant density, which affects distribution and utilization of soil nutrients and solar energy (Rahmatian et al., 2014). According to Campos et al. (2019), efficient solar radiation and production of photo-assimilates are the important pre-requisites for optimum watermelon production. The number of vines per plant also affects the root volume and plant vigour, which in turn influences water and nutrients' uptake and availability. Viana et al. (2008) reported that the lower the number of vine per plant, the higher the root volume and plant vigour and finally the higher yield as a result of improved nutrient and water uptake. The lower yield recorded on watermelon plants without pruning could result from competition for water, nutrients and light (Gomes et al., 2019). Similarly, Muñoz-Rengifo et al. (2018) argued that since watermelon has naturally many branches, 
pruning is advised to keep adequate number of branches, leaves and fruits to enable them to share efficiently the plant resources. In agreement with findings of the current study, Douglas et al. (2001) and Palada and Chang (2003) also reported a significant effect on yield of cucumber and bitter gourd through pruning by removal of lateral shoots.

Based on results of the current study, pruning to three vines with one fruit per vine is therefore, recommended for optimum yield with big-sized fruits of both watermelon cultivars ('Julie F1' and 'Sugar baby').

\section{Acknowledgements}

We thank the Government of Rwanda for supporting this study through the project "Development of market-responsive plant varieties and seed systems to reduce dependence on importation". Authors are thankful to Dative Niyomufasha, Innocent Ndutiye, Eric Sibomana, Immaculée Mukabanana, and Raurence Mukanziza for their enthusiastic involvement in field work.

\section{References}

ALI M.R., HALIM G.M.A., MEHRAJC G.H.H., 2016 - Stages of vine pruning for vine production of bottle gourd varieties and lines in summer season. - J. Biosci. Agric. Res., 9(01): 792-795.

ANWAR N.A., GAD A.A., BARDISI A., ZYADA H.G., 2019 Effect of plant spacing and apical shoot pinching on growth and productivity of watermelon plants under sandy soil conditions. - Zagazig J. Agric. Res., 46(2): 357365.

AYALA-TAFOYA F., LÓPEZ-ORONA C.A., YÁÑEZ-JUÁREZ M.G., DÍAZ-VALDEZ T., DE JESÚS VELÁZQUEZ-ALCARAZ T., DELGADO J.M.P., 2019 - Plant density and stem pruning in greenhouse cucumber production. - Rev. Mexicana Cienc. Agric., 10(1): 79-90.

CAMPOS A.M.D., LUZ J.M.Q., SANTANA D.G., MARQUEZ G.R., 2019 - Influences of plant density and fruit thinning on watermelon hybrid production cultivated in different seasons. - Hortic. Bras., 37(4): 409-414.

DHILLON N.S., SHARMA P., SHARMA K.D., KUMAR P., 2017 - Effect of plant density and shoot pruning on yield and quality of polyhouse grown cucumber. - Environ. Ecol., 35(4B): 3023-3026.

DOUGLAS C., SANDERS U., LARRY M., 2001 - Home garden trellised cucumber. College of Agriculture and life science, North Carolina State University. - Hort. Info. Leaflet, 80114B, pp. 2.
DUBE J., DDAMULIRA G., MAPHOSA M., 2020 Watermelon production in Africa: challenges and opportunities. - Int. J. Veg. Sci., 27(3): 211-219.

EVE B., TUARIRA M., MOSES M., 2016 - The influence of pinching on the growth, flowering pattern and yield of butternuts (Cucurbita moschata). - Int. J. Hort. Orn. Pl., 2(1): 19-25.

FAO, 2020 - FAOSTAT data. - FAO, Food and Agriculture Organization of the United Nations, http://www.fao. org/faostat/en/\#data/QC.

FENG S., MARTINEZ C., GUSMAROLI G., WANG Y., ZHOU J., WANG F., CHEN L., YU L., IGLESIAS-PEDRAZ J.M., KIRCHER S., SCHÄFER E., FU X., FAN L.M., DENG X.W., 2008 - Coordinated regulation of Arabidopsis thaliana development by light and gibberellins. - Nature, 451: 475-479.

GOMES R.F., SANTOS L.D.S., BRAZ L.T., ANDRADE F.L.D.N., MONTEIRO S.M.F., 2019 - Number of stems and plant density in mini watermelon grown in a protected environment. - Pesq. Agropec. Trop., 49: e54196, pp. 1-8.

KABIRIGI M., NGETICH F.K., RUSHEMUKA P., MWETU K.K., WASIGE E.J., RUGANZU V.M., NABAHUNGU N.L., 2017 Implications of tillage practices, management of soil surface and fertilizer application on sustainable dryland agriculture: a case study of Eastern Rwanda. - Afr. J. Agric. Res., 12 (31): 2524-2532.

KONG Q., YUAN J., GAO L., LIU P., CAO L., HUANG Y., BIE Z., 2017 - Transcriptional regulation of lycopene metabolism mediated by rootstock during the ripening of grafted watermelons. - Food Chem., 214: 406-411.

LINS H.A., QUEIROGA R.C.F., PEREIRA A.D.M., SILVA G.D., ALBUQUERQUE J.R.T., 2013 - Growth, yield and quality of fruits of watermelon in function changes in relation sink-source. - Revista Verde de Agroecologia e Desenvolvimento Sustentável, 8(3): 143-149.

MUÑOZ-RENGIFO J., VILLAMAR-TORRES R., MOLINA-VILLAMAR J., CRUZATY L.G., NAVARRETE B.T., MONCADA B.C., OLAYA J.C., MATUTE A.M., ORTEGA-GUEVARA D., JAZAYERI S.M., 2018 - A correct combination of pruning, spacing and organic fertilizer improve development and quality of fruit in watermelon cultivar: case of Ecuadorian littoral. - Biosci. Res., 15(3): 1462-1471.

NAYAK S.R., PARMAR V.K., PATEL A.N., SUCHISMITA J., LATHIYA J.B., TANDEL Y.N., 2018 - Efficacy of pinching and plant growth regulators in enhancing yield characters of cucumber (Cucumis sativus L.). - Int. J. Chem. Stud., 6 (1): 1804-1807.

NDABAMENYE T., VAN ASTEN P.J., BLOMME G., VANLAUWE B., UZAYISENGA B., ANNANDALE J.G., BARNARD R.O., 2013 - Nutrient imbalance and yield limiting factors of low input East African highland banana (Musa spp. AAA-EA) cropping systems. - Field Crop Res., 147: 68-78.

OGA I.O., UMEKWE P.N., 2016 - Effects of pruning and plant spacing on the growth and yield of watermelon (Citrullus lanatus L.) in Unwana-Afikpo. - Int. J. Sci. Res., 
5(4): 110-115.

PALADA M.C., CHANG L.C., 2003 - Suggested cultural practices for bitter gourd. - AVRDC, Public. No. 3-547, pp. 15.

QUEIROGA R.C.F., PUIATTI M., FONTES P.C.R., CECON P.R., 2008 - Produtividade e qualidade de frutos de meloeiro variando número de frutos e de folhas por planta. Hort. Bras., 26: 209-215.

RAHMATIAN A., DELSHAD M., SALEHI R., 2014 - Effect of grafting on growth, yield and fruit quality of single and double stemmed tomato plants grown hydroponically. Hort. Environ. Biotechnol., 55(2): 115-119.

VERDOODT A., VAN RANST E., 2003 - Land evaluation for agricultural production in the tropics: a large scale land suitability classification for Rwanda. - Laboratory of Soil Science, Ghent University, Ghent, Belgium, pp. 176.

VIANA T.V., ALVES A.M., SOUSA V.F., AZEVEDO B.M., FURLAN R.A., 2008 - Planting density and number of drains influencing the productivity of rose plants cultivated in pots. - Hortic. Bras., 26(4): 528-532. 
